\title{
Relationship between the facial bone thickness and gingival biotype of the anterior maxilla in Koreans
}

\author{
Ji-Hun Park, Yeun-Kang Kim, Hyoung-Min Kim, Ji-Young Joo, Ju-Youn Lee* \\ Department of Periodontology, School of Dentistry, Pusan National University, Yangsan, Republic of Korea
}

Purpose: The objects of this study were to examine the thickness of labial plate of anterior maxillary teeth and the gingival biotype in Koreans and to evaluate whether there is a correlation between the gingival biotype and the thickness of labial plate. Materials and Methods: This study was performed on 335 teeth of 57 subjects at the Pusan National University Dental Hospital. Cone Beam Computed Tomography (CBCT) was used to measure the thickness of labial plate at $4 \mathrm{~mm}, 6 \mathrm{~mm}, 8 \mathrm{~mm}$ from the cementoenamel junction and the gingival biotype was determined by the visibility of periodontal probe. Results: Thin facial bone less than $1 \mathrm{~mm}$ was observed in $87 \%$ at $4 \mathrm{~mm}, 88 \%$ at $6 \mathrm{~mm}$ and $90 \%$ at $8 \mathrm{~mm}$. In $21 \%$ of total objects, thin gingival biotype was observed. There is no correlation between the thickness of labial plate and gingival biotype. Conclusion: Additional thorough radiographic examination such as CBCT was mandatory for aesthetic dental implant in the anterior dentition besides clinical oral examination. (J Dent Rehabil Appl Sci 2015;31(3):169-77)

Key words: dental implants; periodontium; Koreans

\section{서론}

상악 전치부는 임플란트 치료에 있어 기능적 요구뿐 만 아니라 심미적 요구도가 높아 환자와 치과의사 모두 에게 부담스러운 치료 부위이다. 전치부 임플란트 치료 에서 이상적인 치은의 심미성을 회복하고 유지하는 것은 매우 어려운 과정이며, ${ }^{1,2}$ 이러한 최종 심미성에는 하부 치조골의 형태가 중요한 영향을 미친다..$^{3-5}$

치주질환이나 외상, 치근흡수, 치근파절 등의 다양한 원인으로 인한 치아 상실은 순측골의 높이나 두께의 부 족을 야기할 수 있다. 순측골의 결손이 있는 부위에 부 족한 치조골을 회복시키려는 노력 없이 임플란트를 식 립 하는 것은 연조직 퇴축, 치은변연 비대칭, 임플란트 지 대주 노출 등의 심미적 문제를 야기할 수 있다. ${ }^{4,5}$ 따라서, 심미적 요구도가 높은 상악 전치부 임플란트에서는 경조

*Correspondence to: Ju-Youn Lee

Associate Professor, Department of Periodontology, School of Dentistry, Pusan National University, 20, Geumo-ro, Mulgeum-eup, Yangsan, 50612, Republic of Korea

Tel: +82-55-360-5202, Fax: +82-55-360-5194, E-mail: heroine@pusan.ac.kr Received: May 11, 2015/Last Revision: July 6, 2015/Accepted: July 27, 2015
직과 연조직 형태를 보존하거나 재생하기 위한 적극적인 처치가 요구된다. ${ }^{5-7}$ 또한 치주조직의 특성과 임플란트 치료에 따른 치주조직 반응에 대한 이해가 필수적이다.

발치 이후 협설 방향뿐만 아니라 수직적으로도 상당한 치조제 흡수가 보고되고 되고 있으며, 특히 치관측 $1 / 3$ 에서의 협측골 소실이 설측 또는 구개측보다 더 큰 것으 로 보고 되었다. ${ }^{8-10} \mathrm{Sanz}$ 등 ${ }^{10}$ 과 Araujo와 Lindhe ${ }^{11}$ 는 발치 후 즉시 임플란트 식립이 발치 후의 협측 골 소실을 막을 수 없으며, 협측골 소실의 정도는 발치 전 협측골 두께가 얇을수록 더 크다고 보고하였다. 상악 전치부 임플란트 치료에 있어 치료 전 협측골 두께는 발치 즉시 임플란트 식립 후의 협측골과 연조직의 반응에 중요한 영향을 미 치며, ${ }^{12-14}$ 연조직을 지지하고 보철 후 협측골 소실을 방지 하기 위해서는 임플란트 식립 후 잔존 협측골 두께가 최 소 $2 \mathrm{~mm}$ 이상이 추천된다. 5,15 
$\mathrm{Kois}^{16}$ 에 따르면 임플란트 수복에 있어 치은 생체형 (gingival biotype)은 심미적인 치료결과를 위한 중요 한 요소 중 하나이며, 얇은(thin) 치은 생체형에서 발 치 후 즉시 단일 임플란트 식립 시에 치은 퇴축이 더 많 이 발생한다고 보고하였다. 또한 Cook 등 ${ }^{17}$ 의 연구에 서 임상적으로 두꺼운(thick) 치은 생체형인 경우 얇 은 생체형 보다 순측골 두께가 두껍고 백악법랑경계 (cementoenamel junction, $\mathrm{CEJ}$ )에서 치조정까지의 거 리가 더 가까운 것으로 나타났다. 따라서 임상적인 치은 생체형의 평가는 하부 골의 해부학적 상태와 임플란트 치료 후의 경, 연조직 반응을 예측하는데 도움이 될 것 이다.

상악 전치부 임플란트의 심미성에 중요한 요소인 순 측골 두께를 측정한 많은 연구들이 보고되고 있으며, 상 악 전치부 순측골 두께는 약 $80 \%$ 이상에서 $1 \mathrm{~mm}$ 이하 인 것으로 보고 되었다. ${ }^{18-20}$ 이러한 연구가 대부분 서양 인을 대상으로 하여, 상대적으로 체구와 악궁의 크기가 작은 동양인, 그 중에서도 한국인을 대상으로 한 연구는 드문 실정이다. Vandana와 Savitha ${ }^{21}$ 그리고 De Rouck 등 $^{22}$ 의 연구에서 치은 생체형에 대한 인종이나 유전의 영향이 있을 가능성을 제시하였다. 한국인을 대상으로 치은 생체형을 조사한 연구가 있으나 ${ }^{23}$ 아직 순측골 두 께와 치은 생체형의 관계를 확인한 연구는 드물다.

본 연구의 목적은 일차적으로 한국인을 대상으로 각 치아 위치에 따른 상악 전치부 순측골 두께와 $\mathrm{CEJ}$ 에서 치조골정까지의 거리, 치은 생체형의 분포 양상을 조사 하고, 이차적으로 치은 생체형과 순측골 두께에 유의한 상관관계가 있는지를 확인하는 것이다.

\section{연구 재료 및 방법}

\section{1. 연구 대상}

2014년 3월부터 2014년 10월까지 8개월 간 부산대 학교치과병원에 내원하여 본 연구 이외의 치료목적으 로 Cone Beam Computed Tomography (CBCT)를 촬영 한, 상악 6전치가 모두 존재하는 전신적으로 건강한 한 국인 환자를 대상으로 하였다. 본 연구는 부산대학교치 과병원 생명윤리심의위원회의 승인 하에 진행되었다 (PNUDH-2014-003).

상악 6전치에 다음에 해당되는 조건을 가진 환자는 연 구대상에서 제외하였다.
- 부정교합, 교정치료 기왕력

- 치주질환

- 최근 6개월 이내에 치주치료의 기왕력

- 치은연하 보철물의 존재(단, 6전치중 하나의 치아에 서만 치은연하 보철물이 있는 사람은 연구대상에 포 함하였으며, 해당 치아만 대상에서 제외하였다.)

최종적으로 57 명의 대상이 본 연구에서 분석되었다. 그 중 5 명의 연구대상에서 하나의 치은연하 보철물이 있어 해당 치아를 제외하였고, CBCT 영상에서 순측골 을 분석하는 과정에서 2 개 치아에서 치근흡수가 발견되 어 추가적으로 분석에서 제외하였다. 총 335 개의 치아 가 평가되었다.

\section{2. СВCT영상 분석}

순측골 두께와 CEJ로부터 치조골정까지의 거리는 $\mathrm{CBCT}$ 영상을 이용하여 측정하였다. PaX-Zenith3D (Vatech, Yongin, Korea)를 사용하여 CBCT 영상을 촬영 하였으며, $105 \mathrm{kVp}, 5.5 \mathrm{~mA}$, Field of view (FOV): $12 \times$ $9 \mathrm{~cm}$, Voxel size: $0.2 \times 0.2 \times 0.2 \mathrm{~mm}$ 로 설정하였다. 이 미지 분석 소프트웨어(Ez3D 2009 professional version 2.1, Vatech, Yongin, Korea)를 사용하여 이미지를 재구 성하고 분석하였다.

영상 측정 시, 각 치아의 근원심 중앙부를 지나고 치조 골에 수직이 되도록 영상의 단면 위치(slice location)를 정하였다(Fig. 1). 또한 각 치아의 절단면에서 치수강의 중앙부를 지나도록 치아의 장축을 설정하고 이 기준 축 에 수직이 되는 가상선을 연장하여 CEJ로부터의 거리 를 측정하였다(Fig. 2, 3). 상악 우측 견치부터 상악 좌측 견치까지 아래 항목들을 측정한 이후 다시 동일한 순서 로 반복 측정하였다.

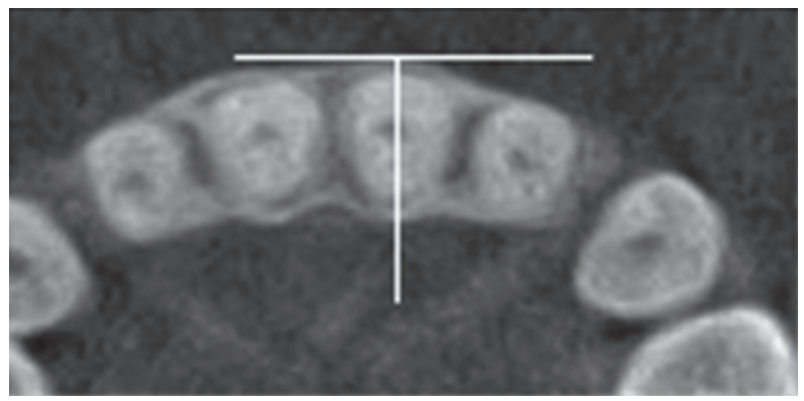

Fig. 1. Slice location in the center of the respective root, perpendicular to the alveolar ridge. 


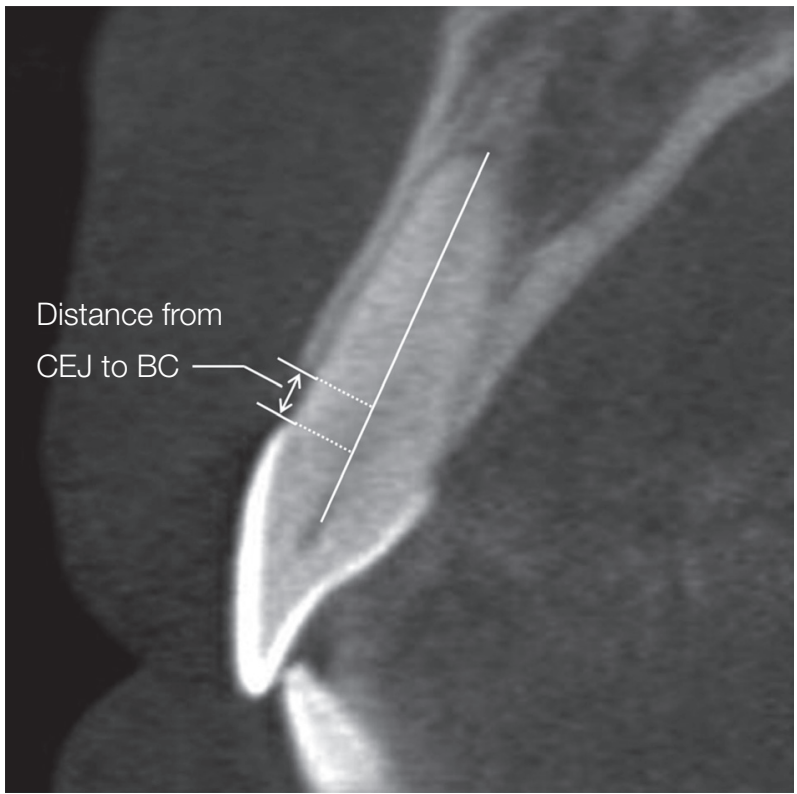

Fig. 2. Distance from the cementoenamel junction (CEJ) to the alveolar bone crest (BC).

- $\mathrm{CEJ}$ 에서 순측 치조골정까지의 거리(Fig. 2)

- $\mathrm{CEJ}$ 에서 $4 \mathrm{~mm}, 6 \mathrm{~mm}, 8 \mathrm{~mm}$ 지점의 순측 치조골 두께(Fig. 3)

$\mathrm{CBCT}$ 영상에서 순측골이 보이지 않는 부위는 순측골 결손(missing bone wall)으로 분류하였다. CBCT 영상 측정은 단일 검사자에 의해 2 회 반복 측정하여 평균값 을 채택하였다.

\section{3. 치은 생체형 결정}

치주탐침자(PGF-W, Osung MND CO., Gimpo, Korea)를 각각의 치아 순면 중앙부에서 치은열구에 삽 입하여 치주탐침자가 변연치은을 통해 비쳐 보이는지의 여부로 평가하였다. 치은을 통해 치주탐침자의 외형이 비치면 “얇은” 생체형(thin biotype)으로, 비치지 않으면 “두꺼운” 생체형” (thick biotype)으로 분류하였다. ${ }^{23-25}$

개인의 치은 생체형은 양 중절치에서 모두 치주탐침 자가 비치는 경우는 “얇은" 생체형으로, 그렇지 않은 경 우는 "두꺼운" 생체형으로 구분하였다.

\section{4. 통계분석}

연구 대상자의 일반적 특징에 대해서는 범주형 자료

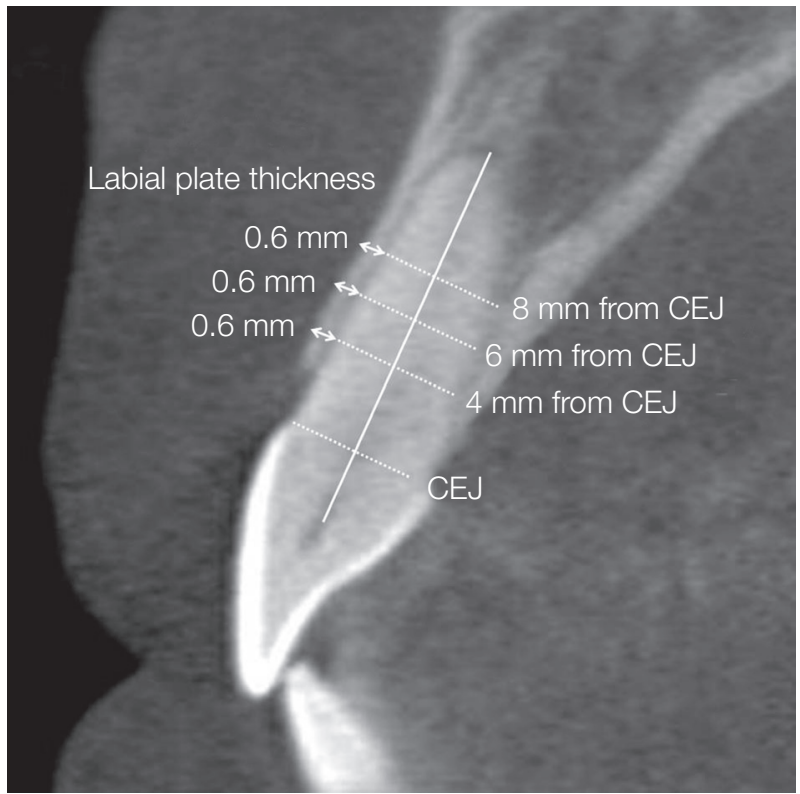

Fig. 3. Labial plate thickness at 4, 6, $8 \mathrm{~mm}$ from the cementoenamel junction (CEJ).

인 경우 빈도와 백분율을, 연속형 자료인 경우 평균 \pm 표준편차를 이용하여 나타내었다. 치은 생체형과 순측 골 두께의 관계 분석에서는 독립 $\mathrm{t}$ 검정(independent t-test)을, 그리고 치아에 따른 CEJ에서 치조정까지 의 거리와 순측골 두께 분석에는 분산분석(analysis of variance)을 사용하였다. 이 때, 사후검정을 위해 쉐페 (Scheffe)의 방법을 이용하였다. 가설 검정 시 사용된 유 의수준은 0.05 이며, 모든 통계분석은 SPSS 21.0 버전 (IBM SPSS Inc., Chicago, IL, USA)을 이용하였다.

\section{결과}

총 57 명의 대상에서 335 개의 치아가 분석되었으며, 연구대상과 치아의 성별, 연령에 따른 분포는 다음과 같 다(Table 1, 2).

\section{CEJ에서 치조골정까지의 거리}

CEJ에서 치조골정까지의 거리는 일반적으로 $3 \mathrm{~mm}$ 이하였다. 치아에 따라 차이가 있었으며, 통계적으로 유 의하였다 $(P=0.034)$. 쉐페의 사후 검정 결과, 중절치보 다 견치에서 $\mathrm{CEJ}$ 에서 치조골정까지의 거리가 더 긴 것 으로 나타났다(Table 3). 
Table 1. Distribution of teeth according to the position

\begin{tabular}{cccccccc}
\hline Tooth no.* & 13 & 12 & 11 & 21 & 22 & 23 & Total \\
\hline No. of analyzed teeth & 57 & 56 & 55 & 55 & 56 & 56 & 335 \\
\hline
\end{tabular}

* FDI tooth-numbering system.

Table 2. Distribution of patients and teeth according to gender and age

\begin{tabular}{llcc}
\hline & & No. of patients & No. of examined teeth \\
\hline All patients & & $57(100 \%)$ & $335(100 \%)$ \\
Sex & Male & $33(57.9 \%)$ & $196(58.5 \%)$ \\
& Female & $24(42.1 \%)$ & $139(41.5 \%)$ \\
Age (years) & $20-29$ & $27(47.4 \%)$ & $158(47.2 \%)$ \\
& $30-39$ & $22(38.6 \%)$ & $130(38.8 \%)$ \\
& $40-49$ & $4(7.0 \%)$ & $24(7.2 \%)$ \\
& $50-59$ & $2(3.5 \%)$ & $12(3.6 \%)$ \\
\end{tabular}

Table 3. Distance from cementoenamel junction (CEJ) to bone crest according to the position of teeth

\begin{tabular}{|c|c|c|c|c|c|}
\hline & $\begin{array}{l}\text { Canine } \\
(\mathrm{n}=97)\end{array}$ & $\begin{array}{l}\text { Lateral incisor } \\
\qquad(\mathrm{n}=103)\end{array}$ & $\begin{array}{l}\text { Central incisor } \\
(\mathrm{n}=106)\end{array}$ & $P^{*}$ & post-hoc comparison** \\
\hline $\begin{array}{c}\text { Distance from CEJ } \\
\text { to bone crest }\end{array}$ & $2.936 \pm 1.398$ & $2.860 \pm 0.826$ & $2.577 \pm 0.807$ & 0.034 & Central incisor $<$ Canine \\
\hline
\end{tabular}

$* P$ values were derived from analysis of variance $(P<0.05)$.

** Scheffe's post-hoc test.

Table 4. Facial bone thickness at 4, 6, and $8 \mathrm{~mm}$ from the cementoenamel junction

\begin{tabular}{cccccc}
\hline & $\begin{array}{c}\text { Canine } \\
(\mathrm{n}=113)\end{array}$ & $\begin{array}{c}\text { Lateral incisor } \\
(\mathrm{n}=112)\end{array}$ & $\begin{array}{c}\text { Central incisor } \\
(\mathrm{n}=110)\end{array}$ & $P^{*}$ & post-hoc comparison** \\
\hline $4 \mathrm{~mm}$ & $0.594 \pm 0.439$ & $0.506 \pm 0.407$ & $0.654 \pm 0.309$ & 0.019 & Lateral $<$ Central \\
$6 \mathrm{~mm}$ & $0.544 \pm 0.497$ & $0.405 \pm 0.658$ & $0.616 \pm 0.324$ & 0.008 & Lateral $<$ Central \\
$8 \mathrm{~mm}$ & $0.327 \pm 0.466$ & $0.170 \pm 0.281$ & $0.645 \pm 0.398$ & 0.000 & Lateral $<$ Central \\
\hline
\end{tabular}

$* P$ values were derived from analysis of variance $(P<0.05)$.

** Scheffe's post-hoc test.

\section{2. 각 측정 부위별 순측골 두께}

각 치아의 순측골 두께는 모든 측정 부위에서 매우 얇 게 측정되었다. $4 \mathrm{~mm}$ 지점에서 견치, 측절치, 중절치 세 집단 간에 통계적으로 유의한 차이가 관찰되었으며 $(P=$ 0.019), 쉐페의 사후검정 결과 측절치와 비교하여 중절 치에서 순측골이 더 두꺼운 것으로 나타나 통계적 유의 성이 입증되었다(Table 4). $6 \mathrm{~mm}$ 와 $8 \mathrm{~mm}$ 지점에서도 중절치에서 측절치와 비교하여 순측골이 유의하게 더
두꺼운 것으로 확인되었다 $(P<0.05$, Table 4). 모든 측 정 부위에서 순측골 두께는 측절치 < 견치 < 중절치 순 으로 두껍게 측정되었으나, 쉐페의 사후검정 결과 측절 치 < 견치, 견치 < 중절치 간에는 유의성이 입증되지 않 았다.

전체 측정 대상 중, $4 \mathrm{~mm}, 6 \mathrm{~mm}, 8 \mathrm{~mm}$ 지점에서 의 순측골 두께가 $1 \mathrm{~mm}$ 이상인 치아의 비율은 각각 $12.8 \%, 11.6 \%, 9.6 \%$ 로 드물게 관찰되었다(Table 5). 
Table 5. Frequency distribution of examined teeth according to the thickness of the facial bone thickness

\begin{tabular}{|c|c|c|c|c|}
\hline \multicolumn{2}{|c|}{ Distance from CEJ } & \multirow{2}{*}{$\frac{\text { Missing bone wall }}{26(23.0)}$} & \multirow{2}{*}{$\frac{\text { Bone wall thickness }<1 \mathrm{~mm}}{67(59.3)}$} & \multirow{2}{*}{$\frac{\text { Bone wall thickness } \geq 1 \mathrm{~mm}}{20(17.7)}$} \\
\hline $4 \mathrm{~mm}$ & Canine $(\mathrm{n}=113)$ & & & \\
\hline & Lateral incisor $(\mathrm{n}=112)$ & $28(25.0)$ & $73(65.2)$ & $11(9.8)$ \\
\hline & Central incisor $(n=110)$ & $10(9.1)$ & $88(80.0)$ & $12(10.9)$ \\
\hline & Total $(\mathrm{n}=335)$ & $64(19.1)$ & $228(68.1)$ & $43(12.8)$ \\
\hline \multirow[t]{4}{*}{$6 \mathrm{~mm}$} & Canine $(\mathrm{n}=113)$ & $31(27.4)$ & $65(57.5)$ & $17(15.0)$ \\
\hline & Lateral incisor $(\mathrm{n}=112)$ & $42(37.5)$ & $62(55.4)$ & $8(7.1)$ \\
\hline & Central incisor $(n=110)$ & $10(9.1)$ & $86(78.2)$ & $14(12.7)$ \\
\hline & Total $(\mathrm{n}=335)$ & $83(24.8)$ & $213(63.6)$ & $39(11.6)$ \\
\hline \multirow[t]{4}{*}{$8 \mathrm{~mm}$} & Canine $(\mathrm{n}=113$ ) & $60(53.1)$ & $44(38.9)$ & $9(8.0)$ \\
\hline & Lateral incisor $(\mathrm{n}=112)$ & $78(69.6)$ & $33(29.5)$ & $1(0.9)$ \\
\hline & Central incisor $(\mathrm{n}=110)$ & $16(14.5)$ & $72(65.5)$ & $22(20.0)$ \\
\hline & Total $(\mathrm{n}=335)$ & $154(46.0)$ & $149(44.5)$ & $32(9.6)$ \\
\hline
\end{tabular}

CEJ, cementoenamel junction.

Table 6. Frequency distribution of gingival biotype

\begin{tabular}{llcc}
\hline & & Thin biotype & Thick biotype \\
\hline Gender & Male (33) & $6(18 \%)$ & $27(82 \%)$ \\
& Female (24) & $6(25 \%)$ & $18(75 \%)$ \\
\multirow{2}{*}{ Tooth position } & Canine (113) & 51 & 62 \\
& Lateral (112) & 46 & 66 \\
& Central (110) & 22 & 88 \\
\hline
\end{tabular}

Table 7. Facial bone thickness according to the gingival biotype

\begin{tabular}{|c|c|c|c|c|c|c|}
\hline \multirow{2}{*}{\multicolumn{2}{|c|}{ Distance from CEJ }} & \multicolumn{2}{|c|}{ Thin biotype } & \multicolumn{2}{|c|}{ Thick biotype } & \multirow{2}{*}{$P^{*}$} \\
\hline & & Mean $(\mathrm{mm})$ & $\mathrm{SD}(\mathrm{mm})$ & Mean $(\mathrm{mm})$ & $\mathrm{SD}(\mathrm{mm})$ & \\
\hline \multirow{3}{*}{$4 \mathrm{~mm}$} & Canine & 0.541 & 0.413 & 0.637 & 0.457 & 0.249 \\
\hline & Lateral incisor & 0.478 & 0.353 & 0.526 & 0.442 & 0.546 \\
\hline & Central incisor & 0.632 & 0.250 & 0.659 & 0.324 & 0.713 \\
\hline \multirow{3}{*}{$6 \mathrm{~mm}$} & Canine & 0.416 & 0.417 & 0.650 & 0.535 & 0.012 \\
\hline & Lateral incisor & 0.241 & 0.330 & 0.520 & 0.794 & 0.027 \\
\hline & Central incisor & 0.623 & 0.430 & 0.615 & 0.295 & 0.919 \\
\hline \multirow{3}{*}{$8 \mathrm{~mm}$} & Canine & 0.171 & 0.326 & 0.455 & 0.523 & 0.001 \\
\hline & Lateral incisor & 0.117 & 0.239 & 0.206 & 0.303 & 0.087 \\
\hline & Central incisor & 0.727 & 0.535 & 0.624 & 0.356 & 0.397 \\
\hline
\end{tabular}

$* P$ values were derived from independent $\mathrm{t}$ test $(P<0.05)$.

CEJ, cementoenamel junction.

\section{3. 치은 생체형과 순측골 두께의 관계}

개인의 대표 값으로 설정한 치은 생체형에서는 총 57 명의 연구대상 중 12 명 $(21 \%)$ 에서 "얇은" 치은 생체형이 관찰되었다(Table 6). 치아 위치에 따른 치은 생체형에 서는 전반적으로 “두꺼운” 유형이 더 빈번하게 관찰되
었다.

전반적으로 “얇은” 생체형보다 “두꺼운” 생체형에서 더 두꺼운 순측골 두께가 관찰되었으나, 견치의 $6 \mathrm{~mm}$, $8 \mathrm{~mm}$ 지점과 측절치의 $6 \mathrm{~mm}$ 지점에서만 치은 생체형 과 순측골 두께 사이의 통계적 유의성이 관찰되었다 $(P$ $<0.05$, Table 7). 


\section{고찰}

상악 전치부 임플란트에서 심미적인 순측 치은 경계 의 장기적인 안정성을 위해서는 충분한 높이와 폭의 순 측골이 필수적이며, 순측골 높이는 임플란트 치료 후 순 측 치은 변연의 위치에 영향을 미친다. ${ }^{3,25,26}$ 본 연구에서 CEJ에서 순측 치조골정까지의 평균 거리는 $3 \mathrm{~mm}$ 이하 로 건강한 치주조직에서의 다른 연구 결과들과 유사하 게 측정되었다. ${ }^{19,27}$ 이는 본 연구의 대상 대부분이 20 30 대에 집중되어 있어 상대적으로 치주적으로 건강한 대상이 포함되었기 때문으로 해석할 수 있을 것이다.

임플란트의 심미적 측면에서, 치조정 부위의 골이 치 은 변연을 지지하고 치조돌기의 형태를 결정하기 때문 에 ${ }^{25}$ 본 연구에서 $4 \mathrm{~mm}$ 지점에서의 순측골 두께가 임상 적으로 중요하다고 평가할 수 있다. 본 연구 결과, $4 \mathrm{~mm}$ 지점에서의 평균 순측골 두께는 견치 $0.594 \mathrm{~mm}$, 측절치 $0.506 \mathrm{~mm}$, 중절치 $0.654 \mathrm{~mm}$ 로 서양인을 대상으로 같 은 부위의 평균 순측골 두께를 측정한 Braut 등 ${ }^{25}$ 의 연구 결과와 유사하였다. 그러나, 본 연구 결과와 비교 시 더 두꺼운 순측골 두께를 보고한 연구들도 있었다. ${ }^{20,27}$ 이는 구체적인 측정방법의 차이에서 기인한 것으로, 두껍게 측정된 연구 ${ }^{20,27}$ 에서는 치조골정을 기준점으로 하여 일 정 거리에서의 순측골 두께를 측정한 반면, 이번 연구와 Braut 등 ${ }^{25}$ 의 연구에서는 $\mathrm{CEJ}$ 에서 $4 \mathrm{~mm}$ 지점의 순측골 두께를 측정하였다. 결과적으로 치조골정의 더 치관측 두께가 측정되거나 또는 순측골이 존재하지 않는 부위 $(0 \mathrm{~mm})$ 도 존재하여, 최종적으로 더 얇은 순측골 두께가 관찰되게 되었다고 보여진다. 또한 Ghassemian 등 ${ }^{19}$ 과 Braut 등 $^{25}$ 의 연구에서는 측절치의 평균 순측골 두께가 중절치나 견치와 비교하여 더 두꺼웠으며, 이는 측절치 에서 치근의 직경이 감소되어 중절치나 견치와 비교하 여 치근 풍융도가 감소하기 때문이라고 하였다. 본 연구 에서는 $4 \mathrm{~mm}, 6 \mathrm{~mm}, 8 \mathrm{~mm}$ 지점 모두에서 측절치의 순 측골이 가장 얇게 측정되었다. 또한 측절치 치근 직경이 감소한 만큼 더 두꺼운 순측골을 보이지는 않았고, 오히 려 인접치와 비교하여 치근과 순측골이 함께 구개측으 로 위치되어 있었다.

본 연구에서는 순측골 결손이 전체 측정 치아의 $54 \%$ 로 높게 확인되었다(자료는 첨부하지 않았음). 일반적 으로 $\mathrm{x}$ 선 산란(x-ray scattering)으로 인한 노이즈(noise) 는 FOV가 감소할수록 감소하기 때문에, 적은 볼륨의 $\mathrm{CBCT}$ 촬영장비에서 노이즈가 적고 큰 $\mathrm{FOV}$ 의 $\mathrm{CBCT}$
촬영장비에서는 가장 작은 voxel size를 선택하지 않으 면 이미지 해상도의 감소가 있다. ${ }^{28}$ 그러나 본 연구의 연 구대상에서는 순측골 계측을 목적으로 $\mathrm{CBCT}$ 영상을 획 득하지 않았기 때문에 촬영 시 가장 작은 voxel size가 선 택되지 않았다. 따라서 순측골 측정 시에 $0.2 \mathrm{~mm}$ 미만 의 순측골이 확인되지 않았다는 점에서 볼 때 $0.2 \mathrm{~mm}$ 미만의 매우 얇은 순측골의 경우 영상 획득과정에서의 노이즈에 의해 골 소실이 있는 부위와 구분되지 않은 것 으로 생각된다. 그러나 Araujo와 Lindhe ${ }^{11}$ 에 따르면 발 치 후 골의 remodeling 과정에서 다발골(bundle bone) 의 흡수로 인한 협측골 흡수는 필연적으로 발생하기 때 문에, 임상적으로 $0.2 \mathrm{~mm}$ 미만의 차이가 임상적 진단과 정에서 중요하지 않을 것으로 사료된다.

상악 전치부 임플란트 치료에 있어 협측골 두께가 발 치 즉시 임플란트 식립 후의 협측골과 연조직의 유지에 중요하다. ${ }^{12-14}$ 발치와에 즉시 임플란트 식립 시에 두꺼운 골벽 $(>1 \mathrm{~mm})$ 에서 얇은 골벽 $(\leq 1 \mathrm{~mm})$ 보다 임플란트 표면과 발치와 벽 사이의 공간에 골 재생이 더 많은 것 으로 보고되고 있다. ${ }^{14}$ Braut 등 ${ }^{25}$ 의 연구에서 상악 6전치 중 $\mathrm{CEJ}$ 로부터 $4 \mathrm{~mm}$ 지점에서 순측골이 없는 치아가 23 $32 \%$, 얇은 순측골 $(<1 \mathrm{~mm}) 60-67 \%$, 두꺼운 순측골 $(\geq 1$ $\mathrm{mm}) 5-12 \%$ 이며, 측절치에서 상대적으로 두꺼운 순측골 ( $\geq 1 \mathrm{~mm}$ )이 많다고 보고하였다. 본 연구에서도 두꺼운 순 측골 $(\geq 1 \mathrm{~mm})$ 의 비율은 앞서 언급한 Braut 등 ${ }^{25}$ 과 Huynh$\mathrm{Ba}$ 등 $^{20}$ 의 연구와 유사하게 낮은 빈도로 관찰되었다. 따 라서, 한국인의 상악 전치 순측골은 대부분 매우 얇고 심미적 상악 전치 임플란트를 위해서는 임플란트 식립 시에 순측골 소실을 보상하기 위한 적극적인 수술 계획 이 필요할 것으로 보인다.

본 연구에서 확인된 얇은 치은 생체형을 가지는 대상 은 총 57명 중 12명(21\%)으로 De Rouck 등 ${ }^{22}$ (28\%)과 Lee 등 ${ }^{23}(22 \%)$ 의 연구 결과와 유사하였다. 치주탐침자 를 통한 치은 생체형을 측정하는 방법은 De Rouck 등 ${ }^{22}$ 의 연구에서 약 $85 \%$ 의 반복 재현성을 보였으며, 일반적 으로 높은 재현성을 보이는 것으로 받아들여진다. 그러 나, 시인성(probe visibility)을 사용하여 치은 생체형을 결정한 연구들 22,23 에서는 연구 대상의 $20-30 \%$ 에서 얇 은 치은 생체형이 보고된 반면, 치은 두께를 직접 측정 한 연구들 29,30 에서는 치은 두께가 평균 $1 \mathrm{~mm}$ 정도로 보 고되어 치은 생체형의 결정 방법에 따라 다소 차이가 있 는 것으로 생각된다. 이러한 편차를 고려하더라도 상악 전치부에서 보철치료나 임플란트 치료를 계획할 때 치 
은열구를 통해 치주탐침자가 비쳐 보이는 얇은 생체형 인 경우에는 술 후 연조직 퇴축 등의 위험도가 높으므로 심미적 문제를 예방하기 위해 연조직 이식 등의 적극적 인 수술방법을 고려할 필요가 있을 것이다.

치은 생체형과 순측골의 관계에 관하여, $\operatorname{Cook}$ 등 $^{17}$ 은 얇은 치은 생체형은 하방의 얇은 순측골과 연관이 있고, 두꺼운 치은 생체형은 더 두꺼운 순측골을 보인다고 보 고하였다. 그러나 본 연구에서는 전체적으로 얇은 생체 형에서 두꺼운 생체형보다 평균 순측골 두께가 얇은 경 향은 보였으나, 통계적 유의성은 $6 \mathrm{~mm}$ 지점에서 견치 와 측절치, $8 \mathrm{~mm}$ 지점에서는 견치에서만 확인되었다. 따라서, 치주탐침자를 통해 치은 생체형을 평가하는 방 법은 하방의 순측골 두께를 평가하는데 있어 참고자료 로 사용할 수는 있으나 하방의 골 두께를 예측하는 뛰어 난 지표로 보기는 어려우며, 임플란트 치료계획 시에는 $\mathrm{CBCT}$ 를 통한 정확한 진단이 심미적, 기능적으로 장기 적인 성공을 위해 필요할 것으로 생각된다.

\section{결론}

한국인의 상악 전치부 순측골은 대부분이 $1 \mathrm{~mm}$ 이하 로 얇으며, 상악 전치부에서 발치 즉시 임플란트 식립 시에 이상적으로 요구되는 $2 \mathrm{~mm}$ 의 두께를 만족하는 경 우는 매우 드물다. 따라서 상악 전치부의 발치 후 즉시 임플란트 식립 시 술식에 앞서 CBCT 영상을 이용한 기 존의 해부적 형태에 대한 철저한 평가가 필요하다. 대부 분의 경우, 심미적으로 성공적인 임플란트 치료를 위해 서는 임플란트 식립 시에 부가적인 골 증대 술식이 필요 할 것으로 보인다. 또한 치주탐침자를 이용한 치은 생체 형 평가를 통해, 임상에서 임플란트 치료 후 연조직 퇴 축이 예상되는 고위험 환자를 쉽게 구분할 수 있고 이런 경우에는 부가적인 연조직 이식에 대한 고려가 필요할 것이다.

\section{Acknowledgements}

본 연구는 2014년도 부산대학교 치과병원 임상연구비 지원으로 이루어졌음.

\section{Orcid}

Ji-Hun Park http://orcid.org/0000-0003-3224-3878
Yeun-Kang Kim http://orcid.org/0000-0003-4617-5087

Hyoung-Min Kim http://orcid.org/0000-0002-2445-4299

Ji-Young Joo http://orcid.org/0000-0002-4050-5797

Ju-Youn Lee http://orcid.org/0000-0002-0772-033X

\section{References}

1. Phillips K, Kois JC. Aesthetic peri-implant site development. The restorative connection. Dent Clin North Am 1998;42:57-70.

2. Kan JY, Rungcharassaeng K. Site development for anterior single implant esthetics: the dentulous site. Compend Contin Educ Dent 2001;22:221-6, 228, 230-1; quiz 232.

3. Belser UC, Buser D, Hess D, Schmid B, Bernard JP, Lang NP. Aesthetic implant restorations in partially edentulous patients-a critical appraisal. Periodontol 2000 1998;17:132-50.

4. Buser D, Martin W, Belser UC. Optimizing esthetics for implant restorations in the anterior maxilla: anatomic and surgical considerations. Int J Oral Maxillofac Implants 2004;19 Suppl:43-61.

5. Grunder U, Gracis S, Capelli M. Influence of the 3-D bone-to-implant relationship on esthetics. Int J Periodontics Restorative Dent 2005;25:113-9.

6. Salama H, Salama M. The role of orthodontic extrusive remodeling in the enhancement of soft and hard tissue profiles prior to implant placement: a systematic approach to the management of extraction site defects. Int J Periodontics Restorative Dent 1993;13:312-33.

7. Grunder U. Stability of the mucosal topography around single-tooth implants and adjacent teeth: 1-year results. Int J Periodontics Restorative Dent 2000;20:11-7.

8. Pietrokovski J, Massler M. Alveolar ridge resorption following tooth extraction. J Prosthet Dent 1967; 17:21-7.

9. Schropp L, Wenzel A, Kostopoulos L, Karring T. Bone healing and soft tissue contour changes following single-tooth extraction: a clinical and radiographic 12-month prospective study. Int J Periodontics Restorative Dent 2003;23:313-23.

10. Sanz M, Cecchinato D, Ferrus J, Pjetursson EB, 
Lang NP, Lindhe J. A prospective, randomizedcontrolled clinical trial to evaluate bone preservation using implants with different geometry placed into extraction sockets in the maxilla. Clin Oral Implants Res 2010;21:13-21.

11. Araújo MG, Lindhe J. Dimensional ridge alterations following tooth extraction. An experimental study in the dog. J Clin Periodontol 2005;32:212-8.

12. Qahash M, Susin C, Polimeni G, Hall J, Wikesjö UM. Bone healing dynamics at buccal peri-implant sites. Clin Oral Implants Res 2008;19:166-72.

13. Evans CD, Chen ST. Esthetic outcomes of immediate implant placements. Clin Oral Implants Res 2008;19:73-80.

14. Tomasi C, Sanz M, Cecchinato D, Pjetursson B, Ferrus J, Lang NP, Lindhe J. Bone dimensional variations at implants placed in fresh extraction sockets: a multilevel multivariate analysis. Clin Oral Implants Res 2010;21:30-6.

15. Spray JR, Black CG, Morris HF, Ochi S. The influence of bone thickness on facial marginal bone response: stage 1 placement through stage 2 uncovering. Ann Periodontol 2000;5:119-28.

16. Kois JC. Predictable single-tooth peri-implant esthetics: five diagnostic keys. Compend Contin Educ Dent 2004;25:895-6, 898, 900 passim; quiz 906-7.

17. Cook DR, Mealey BL, Verrett RG, Mills MP, Noujeim ME, Lasho DJ, Cronin RJ Jr. Relationship between clinical periodontal biotype and labial plate thickness: an in vivo study. Int J Periodontics Restorative Dent 2011;31:345-54.

18. Braut V, Bornstein MM, Belser U, Buser D. Thickness of the anterior maxillary facial bone wall-a retrospective radiographic study using cone beam computed tomography. Int J Periodontics Restorative Dent 2011;31:125-31.

19. Ghassemian M, Nowzari H, Lajolo C, Verdugo F, Pirronti T, D'Addona A. The thickness of facial alveolar bone overlying healthy maxillary anterior teeth. J Periodontol 2012;83:187-97.

20. Huynh-Ba G, Pjetursson BE, Sanz M, Cecchinato D, Ferrus J, Lindhe J, Lang NP. Analysis of the socket bone wall dimensions in the upper maxilla in relation to immediate implant placement. Clin Oral Implants Res 2010;21:37-42.
21. Vandana KL, Savitha B. Thickness of gingiva in association with age, gender and dental arch location. J Clin Periodontol 2005;32:828-30.

22. De Rouck T, Eghbali R, Collys K, De Bruyn H, Cosyn J. The gingival biotype revisited: transparency of the periodontal probe through the gingival margin as a method to discriminate thin from thick gingiva. J Clin Periodontol 2009;36:428-33.

23. Lee SP, Kim TI, Kim HK, Shon WJ, Park YS. Discriminant analysis for the thin periodontal biotype based on the data acquired from three-dimensional virtual models of Korean young adults. J Periodontol 2013;84:1638-45.

24. Kan JY, Rungcharassaeng K, Umezu K, Kois JC. Dimensions of peri-implant mucosa: an evaluation of maxillary anterior single implants in humans. J Periodontol 2003;74:557-62.

25. Braut V, Bornstein MM, Belser U, Buser D. Thickness of the anterior maxillary facial bone wall-a retrospective radiographic study using cone beam computed tomography. Int J Periodontics Restorative Dent 2011;31:125-31.

26. Buser D, von Arx T. Surgical procedures in partially edentulous patients with ITI implants. Clin Oral Implants Res 2000;11 Suppl 1:83-100.

27. Nowzari H, Molayem S, Chiu CH, Rich SK. Cone beam computed tomographic measurement of maxillary central incisors to determine prevalence of facial alveolar bone width $\geq 2 \mathrm{~mm}$. Clin Implant Dent Relat Res 2012;14:595-602.

28. Benavides E, Rios HF, Ganz SD, An CH, Resnik R, Reardon GT, Feldman SJ, Mah JK, Hatcher D, Kim MJ, Sohn DS, Palti A, Perel ML, Judy KW, Misch CE, Wang HL. Use of cone beam computed tomography in implant dentistry: the International Congress of Oral Implantologists consensus report. Implant Dent 2012;21:78-86.

29. Egreja AM, Kahn S, Barceleiro M, Bittencourt S. Relationship between the width of the zone of keratinized tissue and thickness of gingival tissue in the anterior maxilla. Int J Periodontics Restorative Dent 2012;32:573-9.

30. Kolte R, Kolte A, Mahajan A. Assessment of gingival thickness with regards to age, gender and arch location. J Indian Soc Periodontol 2014;18:478-81. 


\section{한국인의 상악 전치부 순측골 두께와 치은 생체형(gingival biotype)의 상관관계}

박지훈, 김은강, 김형민, 주지영, 이주연*

부산대학교 치의학전문대학원 치주과학교실

목적: 한국인의 상악 전치부 순측골 두께와 치은 생체형(gingival biotype)의 분포 및 상관관계를 평가하는 것이다.

연구 재료 및 방법: 본 연구는 부산대학교치과병원에 내원한 57명의 환자, 335 개의 치아를 대상으로 시행되었다. Cone Beam Computed Tomography (CBCT)를 이용하여 백악법랑경계로부터 $4 \mathrm{~mm}, 6 \mathrm{~mm}, 8 \mathrm{~mm}$ 지점의 순측골 두께를 측 정하였고, 치은 생체형은 치주탐침자를 이용하여 평가하였다.

결과: 대부분의 대상치아에서 $1 \mathrm{~mm}$ 이하의 얇은 순측골 $(4 \mathrm{~mm}$ 지점 $87 \%, 6 \mathrm{~mm}$ 지점 $88 \%, 8 \mathrm{~mm}$ 지점 $90 \%)$ 이 우세하 게 관찰되었고, 전체 대상자의 $21 \%$ 에서 얇은 치은 생체형이 확인되었다. 치은 생체형과 순측골 두께 사이의 유의한 상 관관계는 존재하지 않았다.

결론: 성공적인 전치부 심미 임플란트 치료를 위해서는 치은 생체형 검사 같은 임상적 검사 이외에 순측골 평가를 위한 추가적 $\mathrm{CBCT}$ 등의 방사선 검사가 필수적이다.

(구강회복응용과학지 2015;31 (3): 169-77)

주요어: 치과용 임플란트; 치주조직; 한국인

*교신저자: 이주연

(50612) 경상남도 양산시 물금읍 금오로 20 부산대학교 치과병원 치주과

Tel: 055-360-5202 | Fax: 055-360-5194 | E-mail: heroine@pusan.ac. kr

접수일: 2015년 5월 11일 | 수정일: 2015년 7월 6일 | 채택일: 2015년 7월 27일 